\section{PHOTOGRAPHIC RECORDS OF THE ASIATIC WILDCAT FROM TWO STATES OF INDIA}

\author{
Anant Pande ${ }^{1}$, Anirudh Vasava ${ }^{2}$, Ridhima Solanki ${ }^{3}$, \\ C.M. Bipin ${ }^{4}$ \& Y.V. Jhala ${ }^{5}$
}

1,2,3,4,5 Department of Animal Ecology and Conservation Biology, Wildlife Institute of India, Post Box 18, Chandrabani, Dehradun 248001, India

2 Present Address: Vidyanagar Nature Club, Vidyanagar, Gujarat 388120, India ${ }^{1}$ anant@wii.gov.in (corresponding author), ${ }^{2}$ aniruddh.vasava@gmail.com,

${ }^{3}$ ridhima@wii.gov.in, ${ }^{4}$ bipin@wii.gov.in, ${ }^{5}$ jhalay@wii.gov.in

The Asiatic Wildcat Felis silvestris ornata Gray, 1830 also known as the Indian Desert Cat is one of the five subspecies of the globally widespread Wildcat Felis silvestris Schreber, 1777 (Driscoll et al. 2007). It is legally protected under Schedule-I of the Wildlife Protection Act (1972) of India and also included in CITES Appendix II, but appears as Least Concern in the IUCN Red List database (Driscoll \& Nowell 2010).

The Asiatic Wildcat inhabits dry steppes, savannahs, bush and semi-deserts kind of habitats across southwestern Asia (Nowell \& Jackson 1996). Fairly distributed in western India (Menon 2003; Prater 2005), it has been reported from western and central Rajasthan (Sharma et al. 2003; Chhangani \& Mohnot 2008) including the Thar Desert (Dookia 2007), Jaipur (Sharma 1998), Saurashtra (Singh 1998) and northern Gujarat (Gajera \& Dharaiya 2011). Kankane (2000) reported the presence of the Asiatic Wildcat east of the Aravalli Hills near Jhalawar, Rajasthan. In Maharashtra, it is reported from drier areas such as Shirur, Baramati and Indapur talukas (Gogate 1997) and near Pune (Lamba 1967).

Apart from these sightings, the Asiatic Wildcat's presence has also been recorded from some protected areas in the past. Recently Gupta et al. (2009) reported the presence of the Asiatic Wildcat in Sariska Tiger Reserve, Rajasthan. Earlier it was reported from Pench Tiger Reserve (Gogate 1997; Mukherjee 1998) and Tadoba Tiger Reserve, Maharashtra (Gogate 1997). A

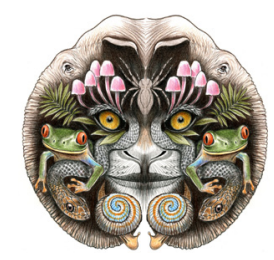

ISSN

Online 0974-7907 Print 0974-7893

\section{OPEN ACCESS} road kill of the species was also found near Semadoh, Melghat Tiger Reserve, Maharashtra (Gogate 1997). Pardeshi et al. (2010) confirmed the presence of the species in the Narayan Sarovar Sanctuary located in the westernmost part of the Kachchh Desert, Gujarat. In Madhya Pradesh, Yoganand (1999) recorded this species from Panna National Park, while the easternmost sighting has been reported from Bagdara Wildlife Sanctuary (Shekhar Kolipaka 2011 pers. comm.). A dead specimen (Image 1b) was also confiscated from a group of Kal Bahelia hunters on the Nauradehi-Jabalpur Road, Madhya Pradesh (Shekhar Kolipaka 2011 pers. comm.). However, it is worth mentioning that only two of above sightings were photographic records and thus, the ones without photographs remain unauthenticated. Kankane (2000) photographed a young individual of the Asiatic Wildcat from Rajasthan while Gupta et al. (2009) reported a camera trap picture of the species from Sariska Tiger Reserve.

We report here the sight records with photographs of the Asiatic Wildcat from two different bio-geographic zones of India (Fig. 2a). The sightings were made during our field work for the "Re-introduction of Cheetah in India" project at Shahgarh landscape, Jaisalmer, Rajasthan and Nauradehi Wildlife Sanctuary, Madhya Pradesh.

DOI: http://dx.doi.org/10.11609/JoTT.o3351.5283-7 | ZooBank: urn:Isid:zoobank.org:pub:6D148CE2-3B9F-40B7-A754-28BC26E59D85 of Threatened Taxa 5(17): 5283-5287; http://dx.doi.org/10.11609/JoTT.o3351.5283-7

Copyright: () Pande et al. 2013. Creative Commons Attribution 3.0 Unported License. JoTT allows unrestricted use of this article in any medium, reproduction and distribution by providing adequate credit to the authors and the source of publication.

Funding: This observations came as byproduct of the research project "Reintroduction of Cheetah In India" funded by Ministry of Environment and Forest (MoEF)

Competing Interest: The authors declare no competing interests.

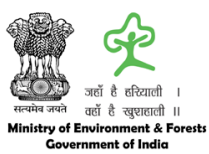

Acknowledgements: The authors thank Director and Dean, WII and Dr. M.K. Ranjitsinh, WTI for their support during the study. We are also grateful to Border Security Force for a great stay at Shahgarh and Mr. J. Devaprasad, DFO, Nauradehi WS for his hospitality. Sincere thanks to experts Dr. C.A. Driscoll, Dr. S. Kolipaka and Dr. S. Mukherjee who helped identify the photographs. We would also like to thank the anonymous reviewers for their valuable comments. 
Shahgarh Landscape, Jaisalmer, Rajasthan: We sighted an individual near Murar $\left(26^{0} 37^{\prime} 6.46^{\prime \prime} \mathrm{N}\right.$ \& $70^{\circ} 01^{\prime} 7.5^{\prime \prime} \mathrm{E}$ ) on 08 August 2011 at $19.36 \mathrm{hr}$ (Fig. 2b). It appeared unperturbed by our presence giving us enough time to photograph it (Image 1a). The body was heavily spotted, dusky brown in color; the lower portion of the tail had dark black rings and was black-tipped. The ears were pointed and had pinkish insides. Two distinct black horizontal stripes on the inside of the forelimbs were also clearly visible. The terrain was slightly undulating with a number of shrubs of Calligonum polygonoides and a sparse distribution of Capparis decidua. Three more individuals were seen after the first sighting; one on the road from Murar to Dhanana $\left(26^{\circ} 42^{\prime} 20.4^{\prime \prime} \mathrm{N} \& 70^{\circ} 11^{\prime} 50.8^{\prime \prime} \mathrm{E}\right)$ on 15 August 2011, another between Dhanana and Lunar $\left(26^{\circ} 22^{\prime} 23.81^{\prime \prime} \mathrm{N}\right.$ \& $\left.70^{\circ} 24^{\prime} 9.86^{\prime \prime} \mathrm{E}\right)$ on 22 August 2011 and the last between

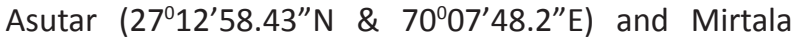
$\left(27^{\circ} 03^{\prime} 20.63^{\prime \prime} \mathrm{N} \& 70^{\circ} 10^{\prime} 40.4^{\prime \prime} \mathrm{E}\right)$ on 25 August 2011. All the sightings happened in broad daylight between 08.00-16.00 hr. However, on all occasions the individuals

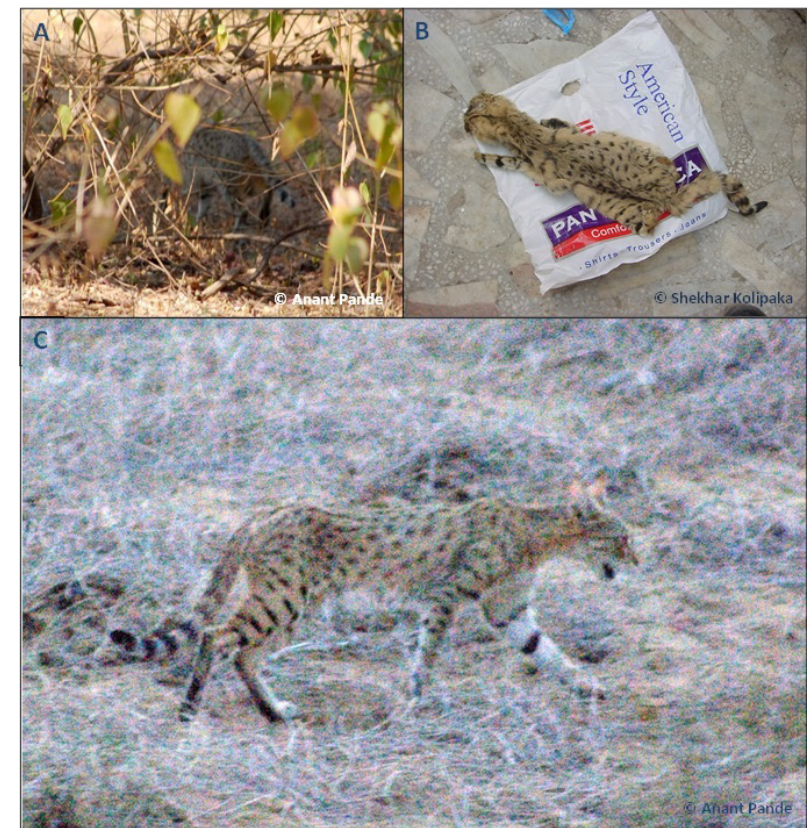

Image 1. A - Asiatic Wildcat in Nauradehi Wildlife Sanctuary, Madhya Pradesh; B - Asiatic Wildcat skin collected near Nauradehi-Jabalpur Road, Madhya Pradesh; C - Asiatic Wildcat at Shahgarh, Rajasthan.

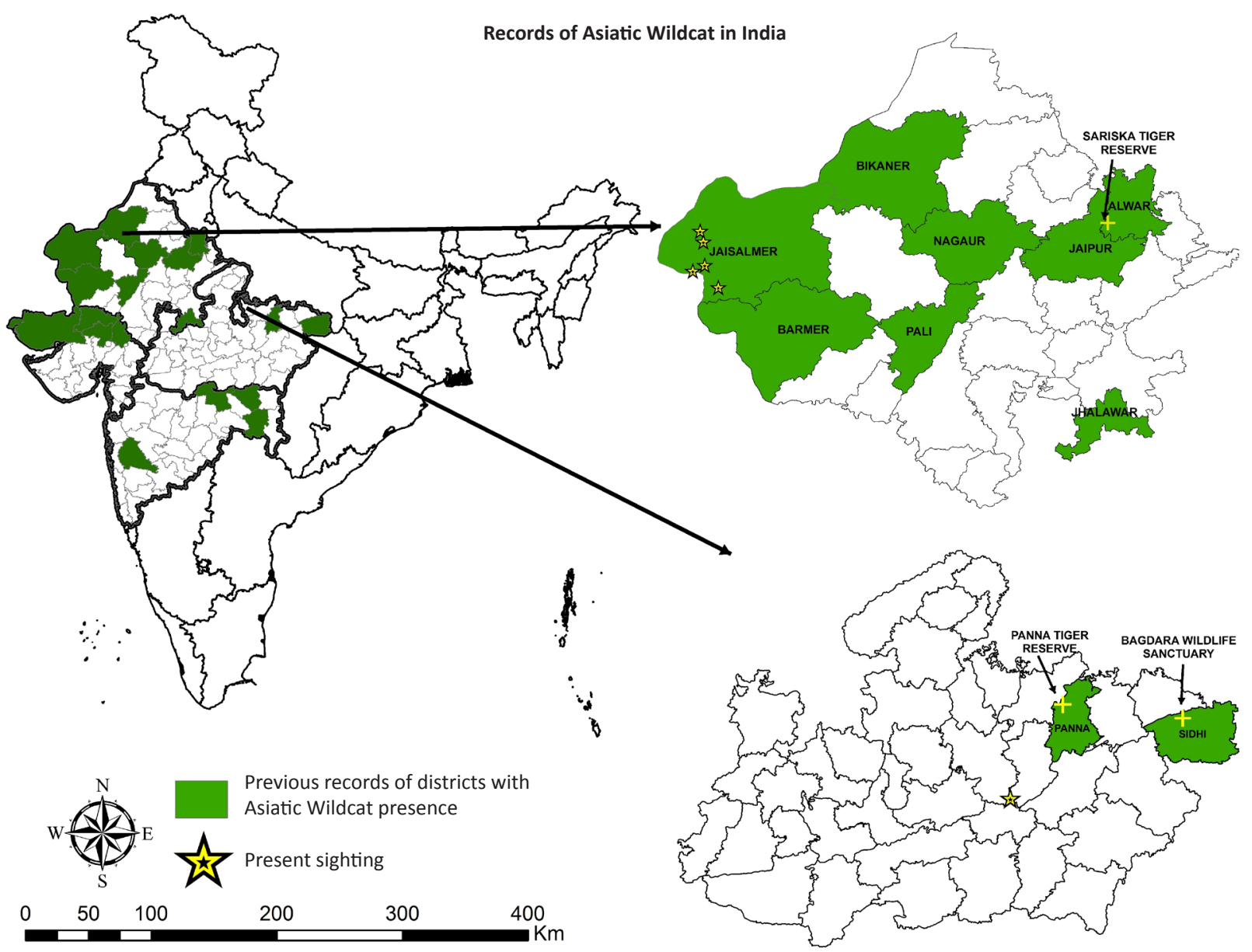

Figure 2a. District-wise distribution map of Asiatic Wildcat based on sight records. 


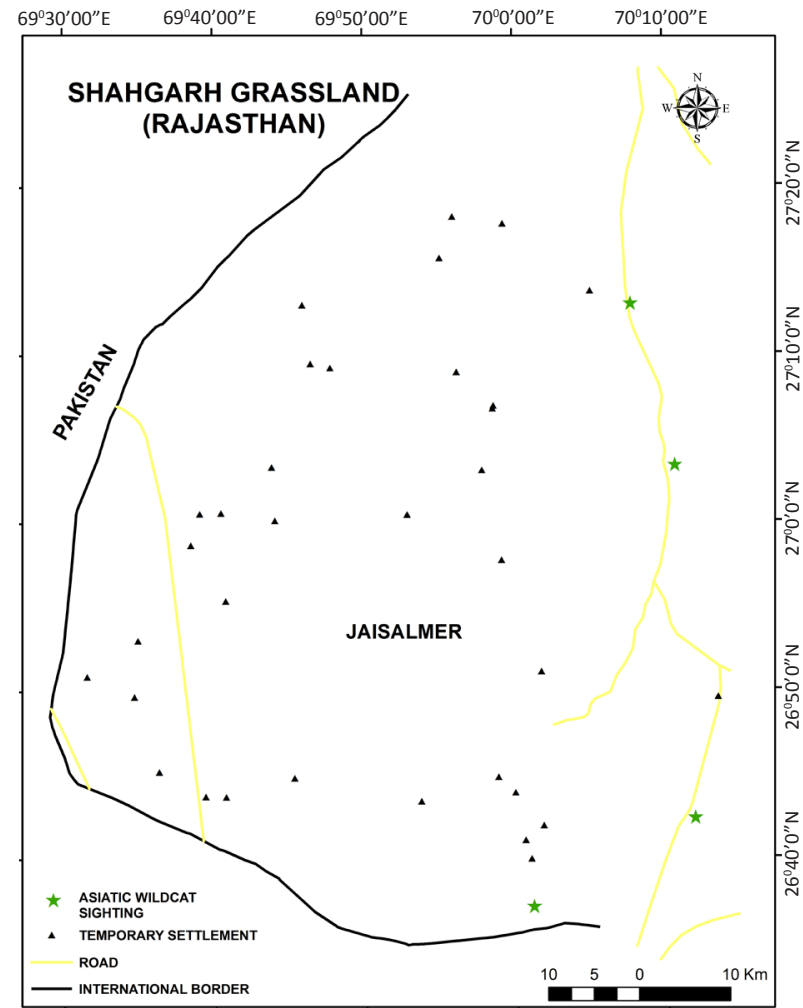

Figure 2b. Sighting locations in Shahgarh grasslands.

ran away quickly from the observers giving no chance to take a photograph.

The Shahgarh Grasslands $\left(27^{\circ} 18^{\prime}-26^{\circ} 47^{\prime} \mathrm{N} \& 69^{\circ} 37^{\prime}-\right.$ $\left.69^{\circ} 29^{\prime} \mathrm{E}\right)$ are located in Jaisalmer District of western Rajasthan covering an area of over $4000 \mathrm{~km}^{2}$ (Ranjitsinh $\&$ Jhala 2010). These grasslands fall in the sand dune covered Desert-Thar (zone 3A) bio-geographic zone of India (Rodgers et al. 2002) and the vegetation of the area is classified as northern tropical thorn forest (6b) - subdivision desert thorn forest-type C1 (Champion \& Seth 1968). The major vegetation of the area includes trees of Capparis decidua, Prosopis cinereria and Salvadora persica; shrubs like Calligonum polygonoides, Leptadenia pyrotechnica and grasses like Lasiurus sindicus, Cenchrus catharticus etc. The habitat also has a good number of prey species of the Asiatic Wildcat like the desert monitor, hare, doves, gerbils, geckos, scorpions and snakes (Anant Pande 2011 pers. obs.).

The area is located along the international border of India and Pakistan and much of the area is under the control of the Border Security Force (BSF) and the Indian army. Due to the harsh climatic conditions and restrictions imposed by the government, the area is sparsely populated by people. Oil and natural gas exploration activities are being carried out at a

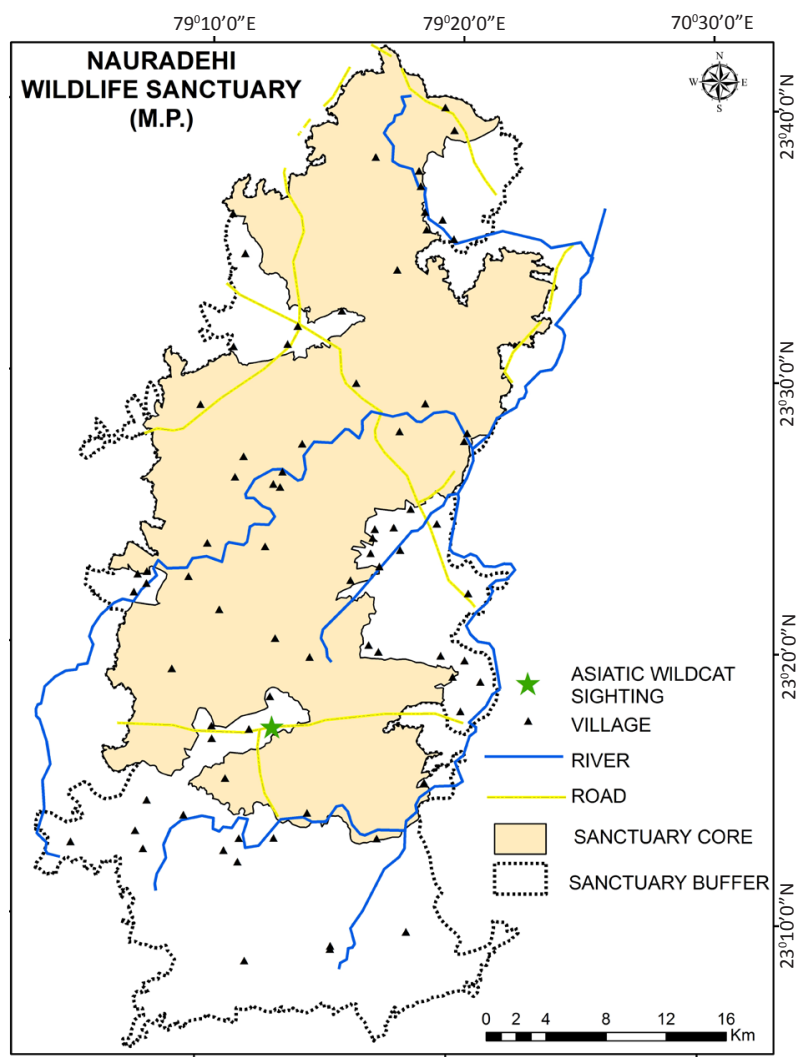

Figure 2c. Sighting location in Nauradehi Wildlife Sanctuary.

few locations here paving the way for infrastructurel development in this fragile ecosystem. Recently, huge reserves of gas were discovered at one of the sites which have accelerated the exploratory and other auxiliary activities in the region (Bhatia 2012, 2013). The Indira Gandhi canal flows along the eastern edge of the landscape and the ecology of the surrounding areas is transforming rapidly due to the invasion of mesic species (Prakash 2001; Idris et al. 2009).

Nauradehi Wildlife Sanctuary, Madhya Pradesh: An individual was seen crossing the road at $14.36 \mathrm{hr}$ on 19 December 2011 near Jhamara Village (at $23^{\circ} 17^{\prime} 0.2^{\prime \prime} \mathrm{N}$ \& $79^{\circ} 12^{\prime} 51.1^{\prime \prime} \mathrm{E}$ ) in Nauradehi range of the sanctuary (Fig. 2c). It crouched first and then started running when we approached it on foot. The body was greyish-brown in color and spotted. We were able to take a picture of only the back portion of the cat before it ran inside the bushes, mostly Lantana camara, thereby blocking a clear view. However, the photograph shows reddish underparts as well as black rings on the terminal portion of the tail based on which it was confirmed as the Asiatic Wildcat. The vegetation of the area was dominated by Chloroxylon sweitenia mixed with Terminalia tometosa and shrubs of Helecteres isora. 
The Nauradehi WS $\left(23^{\circ} 05^{\prime}-23^{\circ} 43^{\prime} \mathrm{N} \& 7^{\circ} 05^{\prime}-\right.$ $79^{\circ} 25^{\prime} \mathrm{E}$ ) covers an area of $1197.04 \mathrm{~km}^{2}$ across three districts of Sagar, Damoh and Narsinghpur in Madhya Pradesh (Ranjitsinh \& Jhala 2010). It lies in the Deccan peninsula (zone 6A) biogeographic zone (Rodgers et al. 2002). The sanctuary continues as a thin strip of forest towards the west into Bareli Tehsil in Raisen District and towards the east it is intermittently connected to the Rani Durgavathi Wildlife Sanctuary in Damoh District and extending up to the Bandhavgarh Tiger Reserve. The extent of this forested landscape is about $5500 \mathrm{~km}^{2}$ (Shukla 2007). The vegetation of the area is classified as southern tropical dry deciduous forest-type $5 \mathrm{~A}$ (Champion \& Seth 1968) represented by dominant tree species of Tectona grandis, T. tomentosa, Lagerstroemia parviflora, Madhuca indica and Chloroxylon sweitenia. Shrubs of Zizyphus mauritiana, Helicteres isora, Holorhina antidysentrica and grasses like Themeda quadrivalvis and Heteropogon contortus are abundant.

There are 74 villages inside the Nauradehi WS of which seven are forest villages and the rest are revenue villages. Livestock grazing, forest fire and illegal timber extraction are of serious concern to park management. Three important roads National Highway 12, Tendukheda-Deori and Sagar-Jabalpur via Mohli bisect the park. Road widening activities are being carried out/planned in some parts of the park to divert more vehicular traffic on these roads causing further disturbance.

Threats and conservation: In common with the other sub-species of wildcat, the Asiatic Wildcat faces considerable threats from habitat loss and poaching (Nowell \& Jackson 1996; Driscoll \& Nowell 2010) although there is a need for dedicated studies to ascertain the extent of these threats to Asiatic Wildcat populations in India. Reclaiming wastelands in the name of planned development has resulted in the destruction of the Asiatic Wildcat habitat and breeding areas in India (Sharma 1998). Although, presently little international trade persists in Asiatic Wildcats, they have been killed in large numbers for their fur in the past (Nowell \& Jackson 1996). In 1979, traders in India declared stocks of 41,845 pelts for an export amnesty (Panwar \& Gopal 1984). Asiatic Wildcat pelts formed a major portion of the small cats' skin seizures by Wildlife Preservation Society of India from Delhi, Srinagar and Puri (1982-1998) (Sanyal 1998). About 97 skins of the species were also recovered from a poacher in Barmer District, Rajasthan (Sharma 1998). Since the wildcat is the progenitor of the domesticated cat $F$. s. catus, there is a high probability of its cross-breeding with the abundant population of feral domestic cats in the vicinity of human settlements, the extent of which remains unclear, especially in the Indian subcontinent.

All the sightings described in the present communication happened during the daytime (except the first) supporting some earlier reports of the species being diurnal (Mukherjee 1998). Although these records may not represent a significant increase of the known geographical range of the Asiatic Wildcat in India, it contributes towards the understanding of its habitat and distribution. No detailed ecological studies exist on Asiatic Wildcats in India and the available information on their distribution and ecology seems to be based exclusively on available opportunistic and often unauthenticated observations. Because of the lack of surveys concentrating on the Asiatic Wildcat, especially in areas beyond their recorded geographical range in India, it is possible that their true occurrence and distribution has gone unnoticed. Their solitary nature and elusive behaviour has largely contributed to such paucity of information on them. Most of the sightings of the species being reported from cultivated landscapes highlight the immediate need of a proper study outside protected areas. Extensive surveys might throw up more light on their distribution, current population status, ecological requirements and the imminent threats they face.

\section{REFERENCES}

Bhatia, V. (2012). Focus Energy finds new gas reserves in Jaisalmer. Times of India, TNN, October 16, 2012. http://articles.timesofindia. indiatimes.com/2012-10-16/jaipur/344983351_gas-reserves-focusenergy-oil-and-gas.

Bhatia, V. (2013). Pak steps on gas to produce oil. Times of India, TNN, April 5, 2013. http://articles.timesofindia.indiatimes.com/2013-0405/jaipur/383053541 barmer-nachna-reserves.

Champion, H.G. \& S.K. Seth (1968). The Forest Types of India. The Manager of Publications, Delhi.

Chhangani, A.K. \& S.M. Mohnot (2008). Demography of migratory vultures in and around Jodhpur, India. Vulture News 58: 23-34.

Dookia, S. (2007). Sighting of Asiatic Wildcat in Gogelao Enclosure, Nagaur in Thar desert in Rajasthan. Cat News 46: 17-18.

Driscoll, C.A., M. Menotti-Raymond, A.L. Roca, K. Hupe, W.E. Johnson, E. Geffen, E.H. Harley, M. Delibes, D. Pontier, A.C. Kitchener, N. Yamaguchi, S.J. O'Brien \& D.W. Macdonald (2007). The near eastern origin of cat domestication. Science 317: 519-523.

Driscoll, C. \& K. Nowell (2010). Felis silvestris. In: IUCN 2011. IUCN Red List of Threatened Species. Version 2011.2. <www.iucnredlist.org>. Downloaded on 26 March 2012

Gogate, M.G. (1997). Smaller cats of Maharashtra. Indian Forester 123(10): 917-923.

Gajera, N. \& N. Dharaiya (2011). Status, occurrence, distribution of some mammals of North Gujarat, India. Proceedings of Zoological Society 64(1): 46-53.

Gupta, S., K. Mondal, K. Sankar \& Q. Qureshi (2009). Record of Desert cat (Felis silvestris ornata) in Sariska Tiger Reserve, Rajasthan. Indian 
Forester 135(10): 1446-1448.

Idris, M., P. Singh \& S. Johari (2009). Impact assessment of the Indira Gandhi canal on the avifauna of the Thar Desert, pp. 119-135. In: Sivaperuman, C., Q.H. Baqri, G. Ramaswamy \& M. Naseema (eds.). Faunal Ecology and Conservation of the Great Indian Desert. Springer Berlin Heidelberg.

Kankane, P.L. (2000). Status survey of Chinkara and Desert Cat in Rajasthan. Zoological Survey of India, Kolkata, 71pp.

Lamba, B.S. (1967). Occurrence of the desert cat, Felis libyca ornata Gray, near Poona. Journal of the Bombay Natural History Society 64(3): 552.

Menon, V. (2003). Desert Cat. In: A Field Guide to Indian Mammals. Dorling Kindersley/Penguin, New Delhi, India, 92pp.

Mukherjee, S. (1998). Cats- some large, many small. In: Mukherjee, S. (ed.). ENVIS (Wildlife and Protected Areas). Wildlife Institute of India, Dehradun 1(2): 5-13.

Nowell K. \& P. Jackson (1996). Wild Cats, Status Survey and Conservation Action Plan. IUCN/SSC cat Specialist group, Gland, Switzerland.

Panwar, H.S. \& R. Gopal (1984). Conservation of wild cats in India, pp. 63-80. In: The Plight of the Cats: Proceedings of the meeting and workshop of the IUCN/SSC Cat Specialist Group at Kanha National Park, Madhya Pradesh, India, 9-12 April 1984. Unpublished report, IUCN/SSC Cat Specialist Group, Switzerland.

Pardeshi, M.K., N. Gajera, R. Patel, D. Worah \& Kumar, V.v. (2010). Species of conservation significance within and vicinity of Narayan Sarovar Sanctuary: Biodiversity and distribution. Biological Forum 2(2): 19-24.
Prater, S.H. (2005). The Desert Cat. In The Book of Indian Animals, Bombay Natural History Society/ Oxford University Press, New Delhi, India, pp. 76-77.

Prakash, I. (2001). Biological invasion and loss of endemic biodiversity in the Thar Desert. Nature Watch. Resonance 76-85. http://www. ias.ac.in/resonance/Mar2001/pdf/Mar2001p76-85.pdf

Ranjitsinh, M.K. \& Y.V. Jhala (2010). Assessing the potential for reintroducing the cheetah in India. Wildlife Trust of India, Noida, \& the Wildlife Institute of India, Dehradun, TR2010/001.

Rodgers, W.A., H.S. Panwar \& V.B. Mathur (2002). Wildlife protected area network in India: a review (executive summary). Wildlife Institute of India, Dehradun.

Sanyal, B. (1998). The smaller cats get less. In: Mukherjee, S. (ed.). ENVIS (Wildlife and Protected Areas). Wildlife Institute of India, Dehradun 1(2): 32-33.

Sharma, V.D. (1998). Small cats in Rajasthan. In: Mukherjee, S. (ed.). ENVIS (Wildlife and Protected Areas). Wildlife Institute of India, Dehradun 1(2): 14-17.

Sharma, S., S.K. Sharma \& S. Sharma (2003). Notes on mammalian fauna of Rajasthan. Zoos' Print Journal 18(4): 1085-1088; http:// dx.doi.org/10.11609/JoTT.ZPJ.18.4.1085-8

Singh, H.S. (1998). Records of small cats in Gujarat. In: Mukherjee, S. (ed.). ENVIS (Wildlife and Protected Areas). Wildlife Institute of India, Dehradun 1(2): 22-23.

Shukla, A. (2007). Management plan for Noradehi Sanctuary: For the period 2007-08 to 2016-17, Forest Department, Government of Madhya Pradesh.

Yoganand, K. (1999). The Desert Cat Felis lybica in Panna National Park. Journal of Bombay Natural History Society 96(1): 130. 